\title{
What comes after standardised packaging for tobacco?
}

\author{
The industry should pay a levy to provide sustainable funding for tobacco control policies
}

\author{
Nicholas S Hopkinson reader in respiratory medicine \\ NIHR Respiratory Biomedical Research Unit, Royal Brompton and Harefield NHS Foundation Trust, London SW3 6NP, UK
}

The tobacco industry is on course to kill around one billion people in the 21 st century, ${ }^{1}$ with a global social burden costing an estimated $\$ 2.1$ tr a year. ${ }^{2}$ Smoking related disease remains the number one cause of preventable deaths in the UK. The implementation of regulations for standardised packaging of tobacco products on 20 May in the UK and France, with Ireland soon to follow, therefore represents an important step forward for public health. These "plain packs" will be a drab brown colour, with product branding restricted to the name as text in a standard font. The revised EU Tobacco Products Directive, which is being implemented at the same time, contains additional requirements such as minimum pack sizes, larger combined picture and text health warnings to cover $65 \%$ of the front and the back of packets, and prohibition of characterising flavours, including menthol, from 2020.

Preventing the uptake of smoking is a child protection issue. More than 200000 children start smoking in the UK each year, ${ }^{3}$ and exposure to tobacco marketing is known to increase this risk. ${ }^{4}$ Standardised packaging removes colourful branding that distracts from health messages ${ }^{4}$ and glamorises smoking. Such branding acts as a form of silent advertising, particularly when other forms of tobacco advertising are banned. MPs in the UK voted overwhelmingly to introduce standardised packaging after Cyril Chantler's independent review in 2014, which concluded that there was good evidence to support the measure ${ }^{5}$ and also rejected misleading tobacco industry opposition. ${ }^{6}$

Although standardised packaging reduces cues to smokers and former smokers to want to smoke, the main effect is expected to be on uptake of smoking. The effect on overall smoking prevalence may therefore be modest in the short term. However, data from Australia, where standardised packaging was introduced in 2012, are encouraging. Australian government data show that smoking rates there are now at an all time low, with average daily smoking prevalence falling from $19.4 \%$ to $17.2 \%$. Modelling suggests that standardised packaging was responsible for about a quarter of this fall. ${ }^{78}$ Importantly, there is no evidence that this has been accompanied by any increase in illicit tobacco consumption - the tobacco industry's consistent argument against such control measures. The industry has been a major culprit in this illicit trade, chastised by, among others, the UK Public Accounts Committee for oversupplying lower tax countries with cigarettes that are subsequently smuggled into higher tax ones like the UK. ${ }^{9}$

A feature common to many tobacco control initiatives has been legal challenge from the tobacco industry as a delaying tactic. The rulings in favour of standardised packaging by the European Court of Justice and the UK High Court are welcome, as was the intergovernmental Permanent Court of Arbitration's description of Philip Morris's challenge to Australian standardised packaging legislation as an "abuse of rights." However, these cases are expensive and time consuming. In addition, there is anxiety that investor-state dispute settlement mechanisms, written into international trade deals, can be used to undermine public health measures in a way that is outside democratic control. The threat of litigation can be discouraging, particularly to low and middle countries. Uruguay's president, Tabaré Vázquez, says of Philip Morris's legal challenge to his tobacco control strategy that "the company wants to make an example of Uruguay and intimidate other countries."10

So where next? The UK has largely implemented international best practice measures set out in the World Health

Organisation's Framework Convention on Tobacco Control. Although the prevalence of smoking has been falling by nearly 0.7 percentage points a year and is now under $19 \%$, there are still nine million smokers in the UK, ${ }^{11}$ and continued progress is threatened by cuts to public health budgets. Sustainable funding is needed for core policies, including tobacco control enforcement, mass media campaigns, and smoking cessation services, many of which are threatened. Decommissioning services is incoherent given the emphasis on prevention in the NHS Five Year Forward View and the fact that smoking cessation support is also one of the most effective treatments for many long term conditions.

The report from Action on Smoking and Health Smoking Still Kills-Protecting Children, Reducing Inequalities ${ }^{12}$ calls for a levy on the tobacco industry to provide sustainable funding for comprehensive tobacco control policies. This principle has been accepted for soft drinks products, which, though harmful, are nowhere near as lethal as tobacco. The government should extend it to tobacco without further delay. 
Competing interests: I have read and understood BMJ policy on declaration of interests and declare the following interests: I am a trustee of Action on Smoking and Health and chair the British Thoracic Society specialist advisory group on chronic obstructive pulmonary disease. Provenance and peer review: Commissioned; not externally peer reviewed.

1 Jha P, Peto R. Global effects of smoking, of quitting, and of taxing tobacco. N Engl J Med 2014;370:60-8. doi:10.1056/NEJMra1308383 pmid:24382066.

2 McKinsey Global Institute. Overcoming obesity: an initial economic analysis. MGI, 2014

3 Hopkinson NS, Lester-George A, Ormiston-Smith N, et al. Child uptake of smoking by area across the UK. Thorax 2014;69:873-5.pmid:24304854.

4 Moodie C, Stead M, Bauld L, et al. Plain tobacco packaging: a systematic review. 2012. http://phrc.lshtm.ac.uk/project 2011-2016 006.html

5 Chantler C. Standardised packaging of tobacco. Report of the independent review undertaken by Sir Cyril Chantler. http://www.kcl.ac.uk/health/packaging-review.aspx, 2014
6 Laverty AA, Watt HC, Arnott D, Hopkinson NS. Standardised packaging and tobacco-industry-funded research. Lancet 2014;383:1384. doi:10.1016/S0140-6736(14) 60499-2 pmid:24726722.

7 Australian Government. Post-implementation review-tobacco plain packaging. 2016 http://ris.dpmc.gov.au/2016/02/26/tobacco-plain-packaging

8 Diethelm PA, Farley TM. Refuting tobacco-industry funded research: empirical data shows decline in smoking prevalence following introduction of plain packaging in Australia. Tob Prev Cess 2015;1:6. doi:10.18332/tpc/60650.

9 Public Accounts Committee. Progress in tackling tobacco smuggling, 2013. http://www. parliament.uk/business/committees/committees-a-z/commons-select/public-accountscommittee/news/tobacco-smuggling-report/

10 Gligorevic T. Uruguay: Anti-tobacco measures have led to $22 \%$ drop in heart attacks. InSerbia News 2014 Jul 18. http://inserbia.info/today/2014/07/uruguay-anti-tobaccomeasures-have-led-to-22-drop-in-heart-attacks/

11 Britton J, Arnott D, McNeill A, Hopkinson N. Tobacco Advisory Group of the Royal College of Physicians. Nicotine without smoke-putting electronic cigarettes in context. BMJ 2016;353:i1745. doi:10.1136/bmj.i1745 pmid:27122374.

12 Action on Smoking and Health. Smoking still kills: protecting children, reducing inequalities. ASH, 2015.

Published by the BMJ Publishing Group Limited. For permission to use (where not already granted under a licence) please go to http://group.bmj.com/group/rights-licensing/ permissions 